\title{
At-sea distribution and habitat of breeding Japanese Murrelets Synthliboramphus wumizusume: implications for conservation management
}

\author{
MARK G. R. MILLER, YUTAKA YAMAMOTO, MAYUMI SATO, \\ BEN LASCELLES, YUTAKA NAKAMURA, HITOSHI SATO, YASUHIRO ANDO, \\ ITSURO EZAKI, PHIL TAYLOR, SHIGEAKI MORI, SEIJI HAYAMA and \\ YUTAKA KOBAYASHI
}

\section{Summary}

The Japanese Murrelet Synthliboramphus wumizusume is a rare, globally 'Vulnerable' seabird, endemic to Japan and South Korea. However, little is known of its at-sea distribution, habitat or threats. We conducted several years of at-sea surveys around Japan to model Japanese Murrelet density in relation to habitat parameters, and make spatial predictions to assess the adequacy of the current Japanese marine Important Bird and Biodiversity Area (IBA) network for the species. During a five-year period, $3,485 \mathrm{~km}$ of at-sea surveys recorded 3,161 Japanese Murrelets around four breeding locations. Maximum murrelet group size was 90 individuals with a mean group size of $2.9 \pm 4.2$ individuals. Models of Japanese Murrelet at-sea density around the two largest breeding locations predicted that almost all murrelets occur within $30 \mathrm{~km}$ of the breeding colony and most within $10 \mathrm{~km}$. Murrelets were predicted closer to the colony in May than in April and closer to the colony at a neritic colony than at an offshore island colony. Additionally, murrelets breeding on an offshore island colony also commuted to mainland neritic habitat for foraging. The marine habitat used by Japanese Murrelets differed between each of the four surveyed colonies, however oceanographic variables offered little explanatory power in models. Models with colony, month and year generated four foraging radii (9-39 km wide) containing murrelet densities of $>0.5 \mathrm{birds} / \mathrm{km}^{2}$. Using these radii the Japanese marine IBA network was found to capture between $95 \%$ and $25 \%$ of Japanese Murrelet at-sea habitat while breeding and appears appropriately configured to protect near-colony murrelet distributions. Given the range of marine habitats that breeding murrelets inhabit, our simple models offer an applicable method for predicting to unsampled colonies and generating ecologically-informed seaward extension radii. However, data on colony populations and further at-sea surveys are necessary to refine models and improve predictions.

\section{Introduction}

The Japanese Murrelet Synthliboramphus wumizusume; hereafter murrelet) is a small seabird endemic to Japan and South Korea and is listed on the IUCN Red List as globally 'Vulnerable' (BirdLife International 2015). With a global population of 2,500-10,000 adults it is the one of the rarest alcids in the world (Carter et al. 2002, BirdLife International 2015). The species was designated as a Japanese 'national monument' in 1972 in recognition of its endemic status and need for 
protection (Hasegawa 1984) but continues to decline and, owing to its rarity, is poorly studied and understood.

Murrelet populations are declining due to terrestrial and marine threats. At monitored breeding sites, human disturbance and predation by introduced rats (Rattus rattus, $R$. norvegicus) and Carrion and Jungle Crows (Corvus corone, C. macrorhynchus) are apparent threats (Carter et al. 2002, Ogi 2008, Croxall et al. 2012). By contrast, the marine threats faced by murrelets are less well known, particularly due to poor data on murrelet at-sea distribution. Accidental bycatch of seabirds at-sea in gillnet fisheries has been identified as a major source of mortality, with alcids the most frequently caught group and the north-west Pacific one of the most high-risk areas (Žydelis et al. 2013). Indeed, the Japanese Murrelet was identified as the second most exposed seabird species to gillnet bycatch in a global assessment (Waugh et al. 2011). Murrelets are taken as bycatch in driftnets and gillnets while foraging near breeding colonies (DeGange et al. 1993, Carter et al. 2002, Ogi 2008), and also in large-scale squid driftnet fisheries while wintering south-east of Hokkaido (Ogi et al. 1993, Piatt and Gould 1994). Piatt and Gould (1994) estimated that in 1990 and 1991, $1-10 \%$ of the adult murrelet population was killed in north-west Pacific drift-net squid fisheries, highlighting the level of threat. In addition to bycatch, murrelets are likely to be threatened by human industrial activities while breeding in Japanese waters, such as oiling and pollution (Camphuysen and Heubeck 2001) and wind farm development (Furness et al. 2013).

To counter such threats, marine conservation in Japan has received increasing attention in recent years. In 2008, the Basic Act on Ocean Policy (Kantei 2007) was adopted, followed by publication of the Marine Biodiversity Conservation Strategy of Japan in 2011 (Ministry of Environment Japan 2011). This government strategy clearly defined Marine Protected Areas (MPAs), and under the definition, legally qualified $8.3 \%$ of Japanese waters as MPAs. Japan now seeks to designate an additional $1.7 \%$ of its exclusive economic zone (EEZ) as MPAs to meet the Convention on Biological Diversity (CBD) Aichi Target 1 (i.e. to conserve $\geq 10 \%$ of biologically and ecologically important national marine areas by 2020 (CBD 2010).

However, the current network of MPAs has received criticism from conservationists and researchers for not adequately representing areas of high marine biodiversity and lacking appropriate management (NACS-J 2012). Since 2010, the Wild Bird Society of Japan (WBSJ) has used BirdLife International's Important Bird and Biodiversity Area (IBA) criteria to identify a network of sites for the conservation of seabirds and marine ecosystems in Japanese waters. Marine IBAs have been identified in waters around breeding colonies, using radii informed by seabird foraging ranges and distribution at-sea (BirdLife International 2010, Thaxter et al. 2012). Although marine IBAs can be delimited more precisely using methods such as seabird tracking, the seaward extension method is recommended as a simple but effective approach, especially when refined using seabird habitat and oceanographic preferences (Thaxter et al. 2012, Soanes et al. 2016).

To assess and mitigate at-sea threats for seabirds, baseline data on at-sea distribution and marine habitat preferences are essential (Lascelles et al. 2014). However, acquiring these data is challenging for seabirds such as murrelets, for which telemetry studies are difficult (Kissling et al. 2015). As such, we conducted ship-based surveys to model the influence of marine habitat variables on the distribution of breeding murrelets while at-sea. We describe: I) habitat variables that influence near-colony murrelet distributions; 2 ) habitat variables that influence foraging murrelet distributions; and 3) the marine habitats of murrelets from different colonies. We use constructed models to predict the extent of murrelet at-sea distribution throughout breeding, and assess the adequacy of the current Japanese marine IBA network to protect the murrelets.

\section{Methods}

\section{Survey data collection}

At-sea surveys for murrelets were conducted around active colonies in four areas: by the WBSJ at Northern Izu islands and Kojine; by Y. Nakamura at Biroujima; and by H. Sato and S. Mori 
at Oki (Figure 1). Surveys were carried out from 2008 to 2012 during the breeding season and predominantly in the incubation phase. All surveys remained in the vicinity of murrelet colonies $(<50 \mathrm{~km})$ and, with the exception of two surveys at Biroujima, were conducted in daylight hours (Table 1). Surveys were made from the bow of a boat, travelling at $20 \mathrm{~km} / \mathrm{hr}$, by $1-4$ observers using binoculars. All diving, floating and flying murrelets were counted within $30 \mathrm{~m}$ of the boat on both sides and a $90^{\circ}$ arc to the bow. Whenever murrelets were encountered, the GPS position was recorded and with the exception of three surveys, the number of murrelets was counted (Table I).

\section{Marine habitat data}

All data handling and statistical analyses were performed in the statistical software environment program R, version 3.I (R Development Core Team 2014), mapping was conducted using QGIS 2.0.1 - Dufour (QGIS Development Team 2013). To model murrelet observations in relation to marine habitat, we used a number of physical and environmental variables potentially correlated with seabird distribution and abundance (Table $\mathrm{S}_{\boldsymbol{I}}$ in the online supplementary materials) (Louzao et al. 2009, Oppel et al. 2012). Static variables, bathymetric depth (BATHY), seabed slope (SLOPE) and minimum distance to land (D_LAND), were extracted or calculated from the GEBCO 30 arcsecond global bathymetry and topography grid (GEBCO 2014). As central-place foragers, the marine habitat accessed by breeding seabirds is heavily influenced by distance from the breeding colony (Grecian et al. 2012, Oppel et al. 2017). We compiled a list of all known murrelet breeding localities in Japan (Table S2) and calculated a 'minimum distance to colony' layer (D_COL) in order to quantify the constraints of central place foraging. Unfortunately, population estimates

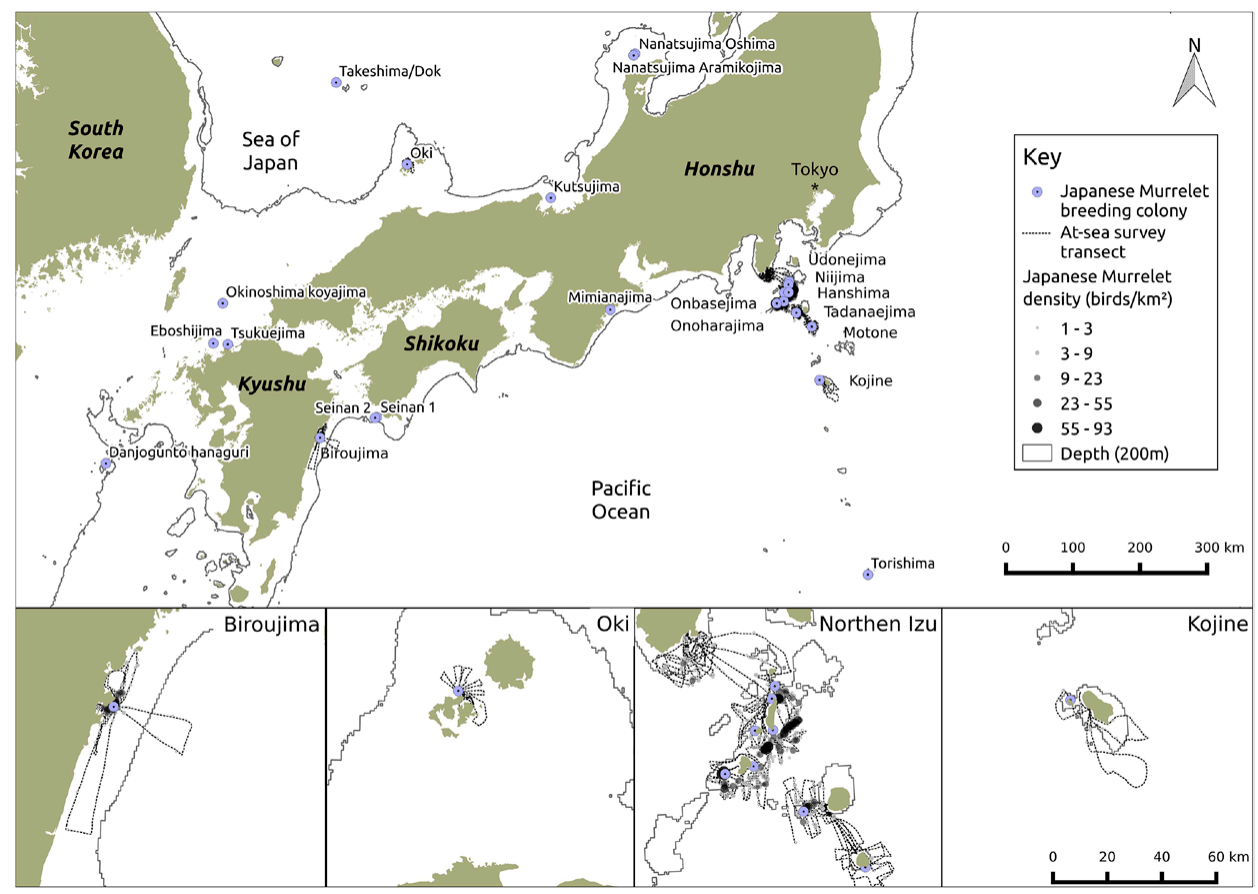

Figure 1 . Japanese Murrelet breeding colony locations in Japan and at-sea survey data undertaken around colonies at Kojine, Northern Izu islands, Biroujima and Oki. Overlapping density counts appear darker. See Table $S_{2}$ for colony details. 
Table 1. Summary of at-sea survey data for Japanese Murrelets collected during this study.

\begin{tabular}{llllll}
\hline Location & Year & Month & Day $(\mathrm{s})$ & Survey area $\left(\mathrm{km}^{2}\right)$ & Mean density $\left(\mathrm{murrelet} / \mathrm{km}^{2}\right)$ \\
\hline Biroujima & 2008 & March & $16-29$ & 83 & 2.17 \\
Biroujima & 2008 & April & $26-27$ & 56 & 2.73 \\
Biroujima & 2009 & March & 07 & 60 & 2.00 \\
Biroujima *+ & 2009 & March & 21 & 31 & \\
Biroujima *+ & 2009 & April & 19 & 58 & \\
Northern Izu islands & 2010 & April & 06 & 450 & 0.97 \\
Northern Izu islands & 2010 & April & 20 & 441 & 0.65 \\
Northern Izu islands & 2010 & May & $11-12$ & 241 & 2.09 \\
Northern Izu islands & 2011 & April & 06 & 823 & 0.42 \\
Northern Izu islands & 2011 & April & 21 & 794 & 0.51 \\
Oki $†$ & 2011 & April & $25-28$ & 185 & 2.31 \\
Northern Izu islands & 2011 & May & 09 & 294 & 0.06 \\
Kojine & 2012 & March & $20-22$ & 266 & 0.52 \\
Biroujima & 2012 & April & $14-16$ & 330 &
\end{tabular}

Night survey data $\left({ }^{*}\right)$, presence-absence data only $(\dagger)$

are unavailable for almost all colonies (but see Carter et al. 2002) and thus the impact of intraspecific competition (Lewis et al. 2001, Wakefield et al. 2017) could not be modelled.

Oceanographic variables sea surface temperature (SST) and chlorophyll-a concentration (CHLA) were created from MODIS Aqua and Terra level 2 satellite image products, downloaded via the OceanColor data portal (http://oceancolor.gsfc.nasa.gov). MODIS level 2 Local Area Coverage (L2_LAC) images are available every $1-2$ days with an approximate spatial resolution of $1 \mathrm{~km}$ but require quality-control processing to remove suspect pixels (Oceancolor 2015). We used ESA BEAM software (BEAM 2014) to georeference and apply quality-control flags to MODIS L2 imagery, processing images to level 3 quality, while maintaining the $\sim$ I km spatial resolution. Standard level 3 imagery has 17 L2 quality-control flags applied to mask pixels, however we included two types of flagged data: HILT (Observed radiance very high or saturated) and STRAYLIGHT (Straylight contamination is likely) because omitting these would have masked out too many pixels in near-shore areas where murrelet surveys took place. We created composite images by averaging temporally consecutive data together, to account for cloud covered pixels in L2_LAC imagery and previous observations that seabird distribution is rarely related to concurrent conditions in SST and CHLA (Louzao et al. 2009, Oppel et al. 2012). Composite CHLA and SST images were created for each unique survey, by averaging all processed images falling within the period of the survey and the three months preceding. A three-month composite window was used following Lavers et al. (2014) to characterise the broad oceanographic conditions of the murrelet incubation period, and to account for the time needed for energy to flow from remotely-sensed primary productivity to higher trophic levels, which constitute seabird prey (Wakefield et al. 2009). Gradient variables (G_CHL and G_SST) were created from the corresponding CHLA and SST composites, using the $3 \times 3$ pixel moving window to identify areas of rapid change between neighbouring pixels. All created environmental variables were stored as layers with $1-k m$ cell size using package 'raster' (Hijmans et al. 2014).

\section{Survey data processing and extraction}

Although standardised survey protocols have at times been adhered to around Biroujima and Northern Izu island colonies, combined multi-year datasets represent a number of survey methodologies. To standardise across surveys, we aggregated the murrelet observation data into a spatial grid at $1-\mathrm{km}$ scale (matching the resolution of the environmental variables). For each survey, grid cells overlaying observations of one or more murrelets were attributed with the sum value, 
and grid cells on the survey route where no murrelets were detected were assigned 'absent'. As survey routes frequently overlapped (occupied the same grid cells) over the multiple years of sampling, murrelets could conceivably be present and absent in the same cell but at different times, allowing for more accurate extraction of temporally dynamic oceanographic variables. With the murrelet data attributed to the $1-\mathrm{km}$ spatial grid we then extracted data from each of the habitat variables based on the corresponding timestamp. The marine habitat of murrelets from each of the four sampled colonies was summarised from SST, CHLA, BATHY and D_LAND values in pixels where one or more murrelets were encountered.

The majority of surveys ( $n=11$ ) in our dataset included count data, however for some surveys $(n=3)$ only presence-absence data were available (Table 1$)$. Count data were selected for modelling as the ability to estimate density is useful for understanding and inference in conservation management (Nielsen et al. 2005). Removing presence-absence data also removed the two Biroujima night surveys. Single surveys of colonies were dropped from modelling due to lack of observations (Kojine) or presence and absence only (Oki). The remaining colonies, Biroujima, and the Northern Izu islands, were well surveyed and were modelled separately due to their geographic differences (Figure I). At-sea observations distant from the colony more accurately reflect preferred habitat for foraging compared to those made near-colony, which are complicated by behaviours unrelated to habitat quality such as transiting to and from the colony and rafting (Wilson et al. 2009, Grecian et al. 2012). Most murrelet observations in our data were made within $20 \mathrm{~km}$ of the colony (Figure 1). However, surveys from the Northern Izu Island colonies recorded a second cluster of observations at distances of $20-50 \mathrm{~km}$ from the colony (Figure $\mathrm{S}_{1}$ ). Using the $>20 \mathrm{~km}$ distance from colony threshold, we took a subset of the Northern Izu Island dataset to represent counts of murrelets that were free of near-colony behaviours and more likely to accurately represent preferred foraging habitat.

\section{Statistical modelling}

Before constructing models, predictor variables were tested for multicollinearity. We calculated a Pearson's correlation score for all possible pairs of variables, using a value of 0.5 and above to identify significantly correlated variables (Dormann et al. 2007). CHLA was significantly correlated with G_CHL and D_COL was significantly correlated with D_LAND, correlated variables were not used together in the same model. Three density models were implemented: 'Biro colony', using the full Biroujima dataset; 'Izu colony', using the full Northern Izu Islands dataset; and 'Izu foraging', using a subset of the Northern Izu Islands dataset for observations $>20 \mathrm{~km}$ from the colony. Murrelet counts were fitted as a response using a generalized linear mixed model (GLMM) framework, in package 'lme4' (Bates et al. 2015). Survey was used as the random intercept to account for differences between surveys, such as weather or observation team (Zuur et al. 2009). We calculated the area of each 1 -km grid cell covered by each survey (between 0.001 and $1 \mathrm{~km}^{2}$ ) and included this as an offset term to account for differences in survey effort between cells. The Izu foraging model was modelled using a Poisson error distribution but the Izu and Biro colony models were over-dispersed due to zero-inflation and modelled using a negative binomial error distribution (Zuur et al 2009). The Izu and Biro colony model terms were selected using forward selection, starting with D_COL, then Month and Year (including interaction terms) and then adding additional environmental variables in turn. The Izu foraging model was built using backward and forward selection, as all variables were assumed to have equal potential influence further from the colony. The support for addition (or removal) of model terms was based on likelihood ratio tests $\left(\chi^{2}\right)$ and confidence intervals (Bolker et al. 2009). We checked model residuals for spatial autocorrelation by calculating Moran's I values over distances: $1-100 \mathrm{~km}$ in the package 'ncf' (Bjornstad 2015) but found no evidence of significant spatial autocorrelation. Goodness-of-fit was assessed for GLMMs split into marginal (var. explained by fixed effects) and conditional (var. explained by fixed + random effects) pseudo $\mathrm{R}^{2}$ components (Nakagawa and Schielzeth 2013), in package 'piecewiseSEM' (Lefcheck 2016). Predictive performance was assessed using Pearson's 
and Spearman's rank correlation coefficients between observed and model-predicted murrelet counts (Potts and Elith 2006). Predictive performance was calculated for each model predicting upon its training dataset, and additionally for Biro and Izu colony models, predictive performance was assessed for each model predicting to the other colony.

\section{Spatial prediction}

To assess the adequacy of the current Japanese marine IBA network for breeding murrelets, we used Biro and Izu colony models to predict murrelet at-sea density around all known murrelet colonies (Table S2). We applied a minimum density threshold of $0.5 \mathrm{birds} / \mathrm{km}^{2}$ to model predictions, thereby limiting their extent to areas appropriate for conservation management while protecting core murrelet at-sea densities. For each marine IBA that included a murrelet breeding colony, we calculated the proportion of model-predicted murrelet at-sea distribution that was captured within the marine IBA.

\section{Results}

\section{Survey results}

A total of 3,161 murrelets were recorded in 1,221 at-sea encounters from a total of 3,485 km of surveys undertaken between 2008 and 2012. Murrelets were encountered singularly and in groups of up to 90 individuals with a mean group size of $2.9 \pm 4.2$ individuals. The Northern Izu islands were the most intensely surveyed location with a total of $2,283 \mathrm{~km}$ of surveys; when gridded at $1 \mathrm{~km}$, murrelets were observed in $17 \%$ of surveyed cells. $634 \mathrm{~km}$ of surveys were undertaken at Biroujima, with $21 \%$ of surveyed cells containing murrelets. At Oki $361 \mathrm{~km}$ of surveys were undertaken with $6 \%$ of surveyed cells containing murrelets. At Kojine $205 \mathrm{~km}$ of surveys were undertaken with $3 \%$ of surveyed cells containing murrelets. Mean density of murrelets at-sea was highest around Biroujima colony ( $\left.1.86 \mathrm{murrelet} / \mathrm{km}^{2}\right)$, followed by Northern Izu colonies (1.16 murrelet $/ \mathrm{km}^{2}$ ) and Kojine (0.06 murrelet $/ \mathrm{km}^{2}$ ). Average group size of murrelets was highest at Northern Izu Islands with $3.1 \pm 4.7$ individuals per group, followed by Biroujima with $2.2 \pm 1.6$ individuals per group and Kojine with $1.6 \pm 0.84$ individuals per group.

\section{Marine habitat at different Japanese Murrelet colonies}

The marine habitat in which murrelets were observed, differed significantly between the four surveyed colonies by SST $\left(F_{3}=285.2, P=<\right.$ o.001), CHLA $\left(F_{3}=862.7, P=<0.001\right)$; BATHY $\left(F_{3}=538.6, P=<\right.$ o.001 $)$ and D_LAND $\left(F_{3}=368.8, P=<\right.$ o.0o1; Table 2$)$.

\section{Variables influencing Japanese Murrelet at-sea density}

The at-sea density of murrelets at Biroujima significantly increased closer to the colony $\left(\chi^{2}{ }_{1}=108.8\right.$, $P=<0.001$ ), at $1 \mathrm{~km}$ from the colony mean murrelet at-sea densities ranged from 1.75 to $7 \mathrm{birds} / \mathrm{km}^{2}$ (Figure 2). Their density was dependent on year $\left(\chi_{2}^{2}=26.4, P=<0.001 ; 2008\right.$ being significantly higher than 2009 and 2012) but did not differ between March and April $\left(\chi_{1}^{2}=2.7, P=0.1\right)$. No other environmental variables significantly influenced murrelet density at Biroujima (Table 3 ). The D_COL and YEAR fixed terms accounted for all variation within the survey random term, giving an identical marginal and conditional $\mathrm{R}^{2}$ of 0.37 .

The at-sea density of murrelets at Northern Izu colonies also increased closer to the colony, at I km from the colony, mean murrelet at-sea densities ranged from 3.49 to $6.74 \mathrm{birds} / \mathrm{km}^{2}$ (Figure 2). However, in contrast to Biroujima, where the distribution of murrelet density in relation to colony distance was static over time, the distance at which murrelets were distributed from Northern 
Table 2. Oceanographic characteristics of Japanese Murrelet encounter locations around each surveyed colony. SST = sea surface temperature, CHLA = chlorophyll-a concentration, BATHY = bathymetric depth, D_LAND $=$ distance to land.

\begin{tabular}{llllll}
\hline Colony & $\begin{array}{l}\text { No. of Japanese } \\
\text { Murrelet encounters }\end{array}$ & SST $\left({ }^{\circ} \mathrm{C}\right)$ & CHLA $\left(\mathrm{mg} \mathrm{m}^{-3}\right)$ & BATHY $(\mathrm{m})$ & D_LAND $(\mathrm{km})$ \\
\hline Izu & 867 & $16.48 \pm 0.61$ & $0.58 \pm 1.05$ & $260.42 \pm 186.25$ & $6.92 \pm 3.2$ \\
Biroujima & 330 & $17.25 \pm 0.78$ & $3.62 \pm 2.89$ & $33.81 \pm 59.89$ & $1.79 \pm 2.32$ \\
Kojine & 10 & $17.78 \pm 0.77$ & $0.18 \pm 0.04$ & $224.7 \pm 147.06$ & $5.49 \pm 3.21$ \\
Oki & 14 & $12.69 \pm 0.06$ & $0.44 \pm 0.06$ & $67.93 \pm 22.63$ & $3.34 \pm 2$ \\
\hline
\end{tabular}

Izu colonies changed by month $\left(\chi_{2}^{2}=94, P=<\right.$ o.001 $)$ : murrelets were distributed closer to the Northern Izu colonies in May than in April (Figures 2 and 3). However, there were no significant differences in overall murrelet density between April and May $\left(\chi^{2}{ }_{1}=2.6, P=0.11\right)$, or between 2010 and $2011\left(\chi^{2}{ }_{1}=1.7, P=0.20\right)$. The Izu colony model had a marginal $\mathrm{R}^{2}$ of 0.42 and conditional $\mathrm{R}^{2}$ of 0.56 , indicating that some of the variance in murrelet density was due to survey differences. Additional environmental variables SLOPE (density was higher over shallower seabed slopes; $\chi^{2}{ }_{1}=9.9, P=0.002$ ) and G_SST (density higher at more homogeneous SST gradients; $\chi_{1}^{2}=4.8, P=0.028$ ) also significantly influenced murrelet density at Northern Izu colonies. However, inclusion of these variables added very little to model explanatory power (marginal $\mathrm{R}^{2}$ of 0.44 and conditional $\mathrm{R}^{2}$ of 0.59 ), so, in the interest of transferability of models to unsurveyed colonies, they were dropped from model predictions.

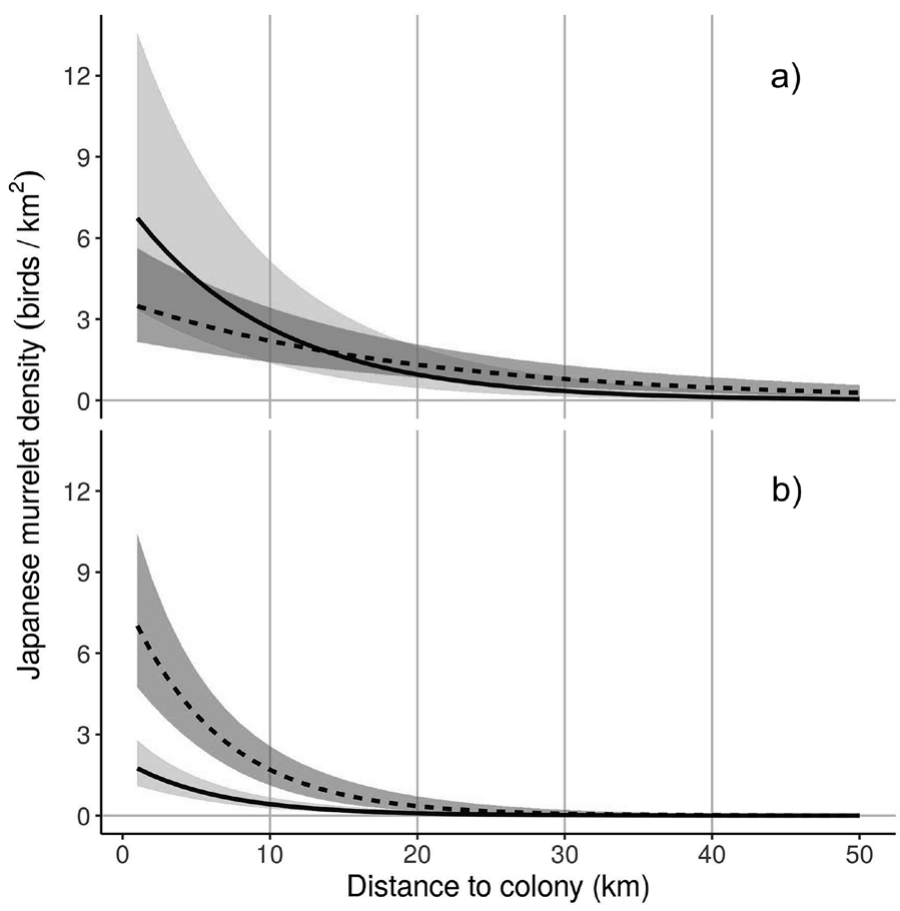

Figure 2. Predicted Japanese Murrelet density (line) and $95 \%$ confidence interval (shade) against colony distance at a) the Northern Izu Islands in April (dotted line, darker shade) and May (solid line, lighter shade); and b) Biroujima in 2008 (dotted line, darker shade) and 2009/2012 (solid line, light shade). 
Table 3. Selected variables and predictive ability of density models. $r$ is the Pearson's correlation coefficient and $p$ the Spearman'r rank correlation coefficient between predicted and observed densities, (train) is predicting upon data used in each model's construction, (test) is predicting upon independent data from the other colony (Biroujima to Izu and vice versa), : denotes an interaction term, all models included a sampling effort offset term. $\mathrm{CHLA}=$ chlorophyll-a concentration, D_COL $=$ distance to colony, D_LAND $=$ distance to land.

\begin{tabular}{|c|c|c|c|c|c|}
\hline Model & Variables & $r($ train $)$ & $p($ train $)$ & $r$ (test) & $p$ (test) \\
\hline $\begin{array}{l}\text { Biroujima colony (negative } \\
\text { binomial GLM) }\end{array}$ & D_COL + Year & 0.46 & 0.48 & 0.12 & 0.15 \\
\hline Izu colony (negative binomial GLMM) & D_COL : Month + (1 | Survey) & 0.30 & 0.23 & 0.25 & 0.36 \\
\hline Izu foraging (poisson GLMM) & D_LAND + CHLA + ( 1 | Survey) & 0.25 & 0.22 & - & - \\
\hline
\end{tabular}

The at-sea density of murrelets foraging at distances $>20 \mathrm{~km}$ from Northern Izu colonies was not influenced by distance to colony $\left(\chi^{2}{ }_{1}=0.56, P=0.451\right)$, month $\left(\chi^{2}{ }_{1}=0.14, P=0.708\right)$ or year $\left(\chi^{2}{ }_{1}=0.67, P=0.415\right)$. The density of foraging murrelets was significantly influenced by distance to land $\left(\chi^{2}{ }_{1}=17.1, P=<0.001\right)$, the model predicted that for every $10 \mathrm{~km}$ further offshore, murrelet density increased by $0.2 \mathrm{birds} / \mathrm{km}^{2}$. The density of foraging murrelets was also slightly influenced by CHLA $\left(\chi^{2}{ }_{1}=4.1, P=0.044\right)$, the model predicted that for every $1 \mathrm{mg} \mathrm{m}^{-3}$ increase in the chlorophyll-a concentration, murrelet density increased by $0.025 \mathrm{birds} / \mathrm{km}^{2}$. The Izu density model had a marginal $\mathrm{R}^{2}$ of 0.05 and conditional $\mathrm{R}^{2}$ of 0.24 , indicating that almost all of the variance in murrelet density was due to survey differences.

\section{Prediction of density models}

The Biro colony model was better than the Izu colony model for predicting murrelet density back onto the sampled colony (Table 3). The Izu colony model was able to predict murrelet density at the Biroujima colony better than the Biro colony model could predict murrelet density at Northern Izu colonies (Table 3). The Izu foraging model was the poorest performing model when predicting to the training dataset and was not used for predicting to independent test data (Table 3). Applying the minimum density threshold of $0.5 \mathrm{birds} / \mathrm{km}^{2}$ to predictions from colony models generated radii of $9 \mathrm{~km}$ distance from Biroujima colony in 2009/2012 (hereafter, Model A) and $18 \mathrm{~km}$ in 2008 (Model B), and radii of $27 \mathrm{~km}$ from Northern Izu colonies in May (Model C) and $39 \mathrm{~km}$ in April (Model D; Figure 3).

\section{Assessment of marine IBA network}

All 22 known murrelet breeding colonies (within Japanese waters) were included in the Japanese marine IBA network (Figure 4). Thirteen marine IBAs overlapped with the 22 murrelet colonies, each created using seaward extensions (though not always centred on a murrelet colony) of between 8 and $120 \mathrm{~km}$. Around the 22 murrelet colonies, the four radii predicted a total area of at-sea habitat where murrelet densities $>0.05$ birds $/ \mathrm{km}^{2}$ of between $4,188 \mathrm{~km}^{2}$ (Model A) and 56,134 $\mathrm{km}^{2}$ (Model D; Table 4). Under the most conservative radius of $9 \mathrm{~km}$ from the colony (Model A), the 13 marine IBAs captured $95 \%$ of murrelet at-sea habitat, by contrast under the most liberal radius of $39 \mathrm{~km}$ from the colony (Model D) marine IBA capture of potential habitat fell to $25 \%$ (Table 4 ).

\section{Discussion}

\section{At-sea distribution and habitat of breeding Japanese Murrelets}

The at-sea density of murrelets in the vicinity of breeding colonies was mostly explained by the distance to the colony, with a contribution from temporal effects. This is consistent with the general dominance of distance to colony in governing habitat use by central-place foraging seabirds (Oppel et al. 2017, Wakefield et al. 2017). Our study period (March-May) covers the later 


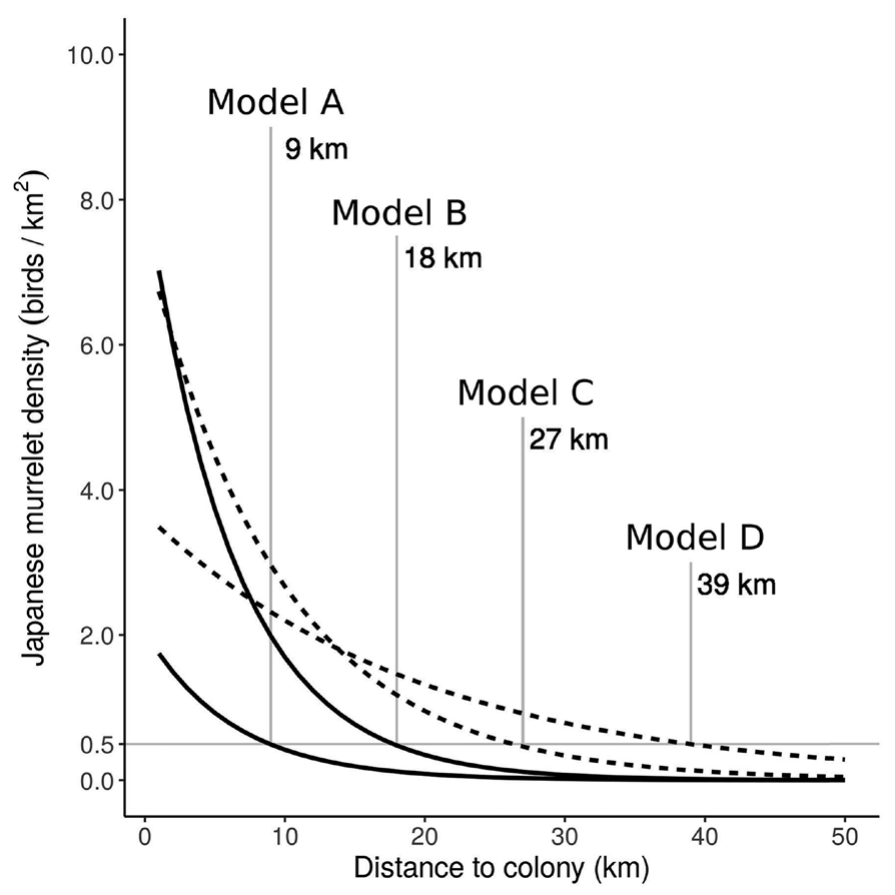

Figure 3. Predicted Japanese Murrelet density against colony distance from the Biroujima colony model (solid line), in 2009/2012 (Model A) and 2008 (Model B); and from the Izu colony model (dotted line), in May (Model C) and April (Model D). The colony distance is given at which density is predicted to fall below $0.5 \mathrm{birds} / \mathrm{km}^{2}$ for each model prediction.

part of pre-laying, the entirety of incubation and the early part of provisioning (Ono 1996). Throughout this time murrelets are constrained to the colony and higher densities in the vicinity of the colony are expected (Grecian et al. 2012). There was no evidence that total murrelet at-sea density differed by month: April no higher than March at Biroujima and May no higher than April at Northern Izu colonies. However, month did interact with distance to colony, showing a shift in at-sea density from more offshore in April to more colony-centred in May. No such change was observed between March and April. Murrelet breeding phenology could explain our results; eggs are laid in March and incubated until hatching in late April and May, at which point parents and their semi-precocial chicks move to the sea (Ono 1996). A more colony-centric at-sea distribution in May relative to April could come from observations of adult murrelets accompanying semiprecocial chicks at-sea. Such family groups are limited in their ability to disperse from the colony by chick flightlessness (Sealy et al. 2015). Murrelet density did not vary by year at Northern Izu colonies but was significantly higher at Biroujima in 2008 relative to 2009 and 2012 . The 2008 Biroujima prediction is likely the most representative estimate of murrelet at-sea density near this colony given that this was the best sampled year. Furthermore, April murrelet densities predicted for Biroujima in 2008 are higher than those for the Northern Izu islands, which is consistent with colony data for Biroujima being the largest single breeding colony for the species with a population of $\sim$ 3,00o individuals (Iida 2008, BirdLife International Tokyo and Wild Bird Society of Japan 2017), compared to the smaller Northern Izu colonies (combined estimated population of 1,000 individuals; Carter et al. 2002). Finally, 2009 was an El Niño year, which impacted Japanese seabirds (Mizutani et al. 2013) and could explain reduced murrelet at-sea density. Further study will be able to elucidate whether inter-annual variance in near-colony at-sea density is an artefact of sampling differences or in response to environmental heterogeneity. 


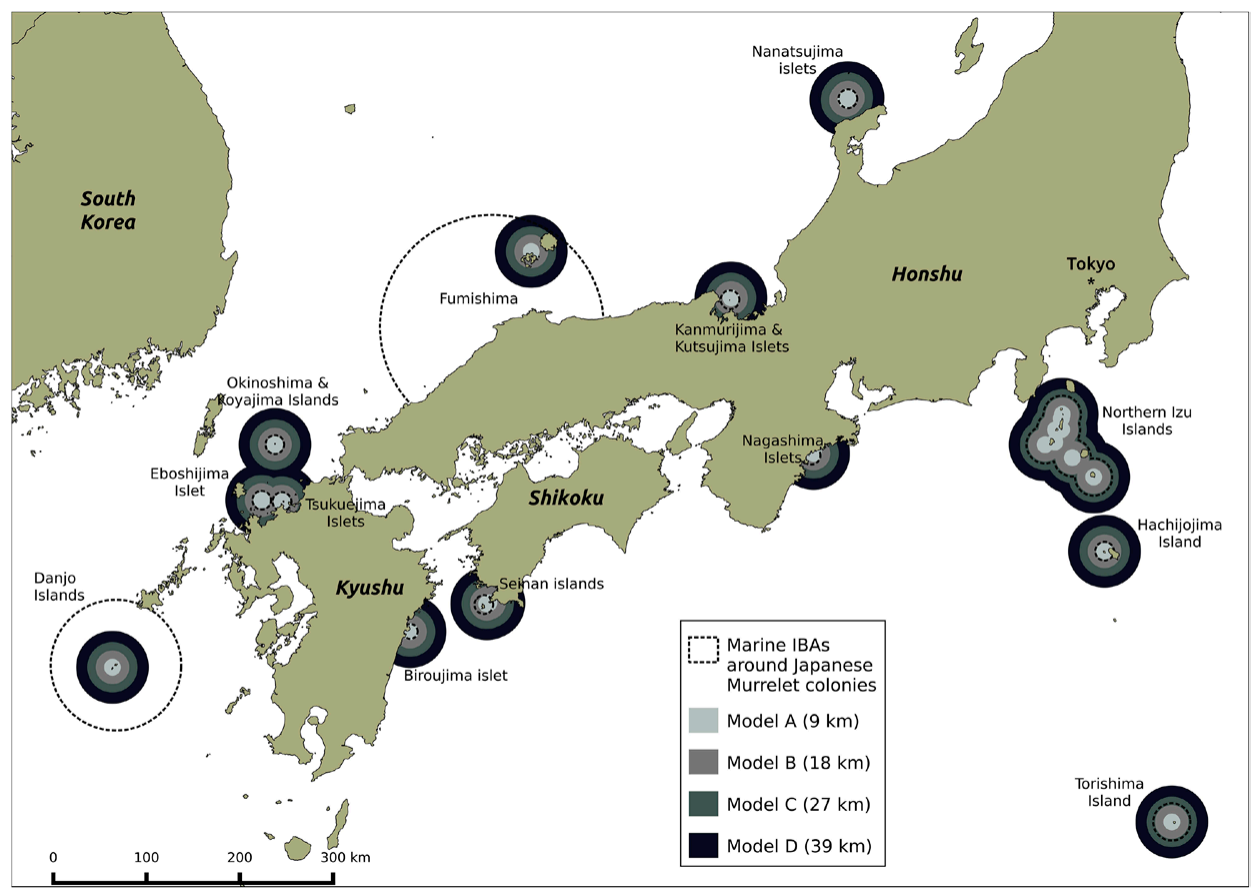

Figure 4. Four radii from model predictions applied to Japanese Murrelet colony locations, and overlap with current Japanese marine IBA network. Each radius is defined as the maximum distance around Japanese Murrelet colonies at which murrelet density is predicted to be above 0.5 birds $/ \mathrm{km}^{2}$. Radii are generated from predictions for: Biroujima in 2009/2012 (Model A); Biroujima in 2008 (Model B); Northen Izu colonies in May (Model C); and Northern Izu colonies in April (Model D).

The more colony-centric distribution of murrelets around the Biroujima colony compared to the Northern Izu colonies could be related to differences in competition pressure and at-sea habitat between the two locations (Paiva et al. 2010b, Oppel et al. 2015). Intra-specific competition pressure should be higher surrounding the more densely populated Biroujima colony than the Northern Izu colonies, but greater foraging distances (sensu Ashmole 1963) were not observed. The likely explanation for this disparity is that higher competition pressure at Biroujima was offset by greater background resource availability from the productive neritic habitat we describe. By contrast, the cooler, deeper, less productive, pelagic habitat experienced by murrelets from offshore Northern Izu island colonies, could limit local resource availability and necessitate greater foraging ranges (Paiva et al. 201ob).

Our exploration of at-sea habitat used by breeding Japanese Murrelets found large differences between colonies. Kojine, at the centre of the Izu island chain is a remote offshore island surrounded by deep, oligotrophic water; whereas Oki, situated in the shallow Sea of Japan, is surrounded by waters $\sim 4^{\circ} \mathrm{C}$ cooler than the other colonies on Japan's East coast that are warmed by the Kuroshio Current. Such different marine habitats are likely to promote different foraging strategies (Paiva et al. 2010a), including different at-sea distributions between populations (Paiva et al. 2010b). The potential for such local adaptation of foraging strategy in the Japanese Murrelet is problematic for applying at-sea distribution findings from studied to unstudied colonies. Additionally, as population estimates are unavailable for most Japanese Murrelet colonies, we could only link at-sea distributions to marine habitat with considerable uncertainty from unknown intra-specific competition pressure. Future study is required to incorporate these data into models and improve accuracy. 
Despite differences in marine habitat between colonies, oceanographic variables explained very little about murrelet density. This could be due to satellite data limitations, such as oceanographic features, which aggregate murrelets for foraging, occurring at spatio-temporal scales beyond the resolution of our data. Alternatively sampling limitations, such as murrelets foraging in excess of $50 \mathrm{~km}$ from colonies and thus beyond the scope of our surveys, as seen in congeners (Shoji et al. 2012), may have obscured relationships between foraging and oceanographic variables. The Izu foraging model, designed to capture foraging habitat, was also unable to contribute much evidence for important oceanographic characteristics of the habitat. Considering the Izu foraging model pragmatically, we observe that all the murrelets distributed $>20 \mathrm{~km}$ from Northern Izu colonies were found north-west of the islands over the mainland shelf. As no other colonies are nearby, we can assume these birds are from Northern Izu colonies and chose neritic habitat $(<200 \mathrm{~m}$ depth) for foraging. Murrelets are thought to forage throughout the water column, feeding on small pelagic fishes and euphausiids (Piatt and Gould 1994) and may favour neritic habitats to prey upon benthic molluscs (Moyer 1957). However, as our surveys around the Northern Izu islands did not extend far into pelagic waters, we cannot discount the possibility that breeding murrelets also target pelagic habitat (e.g. large-scale anticyclonic eddies and warm-core rings; Piatt and Gould 1994) for foraging.

\section{Overlap of current marine IBA network with predicted Japanese Murrelet at-sea density}

Overall the current Japanese marine IBA network appears reasonably well configured to protect murrelets at-sea during breeding. The two marine IBAs capturing almost all murrelet habitat from different model predictions ( $>90 \%$ ) were able to do so due to a large seaward extension radius for a different seabird species: Brown Booby Sula leucogaster (70 km), in the case of Danjo Islands IBA; and Blacktailed Gull Larus crassirostris ( $120 \mathrm{~km}$ ), in the case of Fumishima Islet and Oki Islands IBA (BirdLife International Tokyo and Wild Bird Society of Japan, 2017). The Northern Izu Islands IBA and Torishima Island IBA have $20 \mathrm{~km}$ seaward extensions and perform reasonably well. The remaining marine IBAs were designated based on seaward extension radii of $10 \mathrm{~km}$ or less, hence the steep decline in total marine IBA network coverage of murrelet at-sea habitat from $95 \%$ when murrelets are predicted within $9 \mathrm{~km}$ of colonies, to $52 \%$ when murrelets are predicted within $18 \mathrm{~km}$ of colonies. As such, the effectiveness of the marine IBA network to protect murrelets at a broad scale is dependent upon which model prediction is applied: the network performs well if murrelets are distributed within $9 \mathrm{~km}$ of colonies (Model A) but poorly if they are distributed within $39 \mathrm{~km}$ of colonies (Model D).

This highlights the importance of differences in at-sea murrelet distribution between colonies and the potential for error when predicting to unsampled colonies, especially in different oceanographic regions. Our results, although based only on two breeding locations, suggest that the at-sea murrelet density around a neritic colony cannot effectively predict the more pelagic distribution of an offshore island colony, and that the murrelet density around the offshore island colony, although more informative, cannot fully predict the more colony-centric distribution of the neritic colony. As a speculative recommendation the Izu model predictions could be applied to other offshore island murrelet colonies (Kojine, Torishima, Danjogunto hanagari and Takeshima/Dok) while the Biro model predictions applied to all the other colonies upon the Japanese continental shelf. However, this approach does not account for differences in colony sizes, which are known to impact the foraging range of seabirds via intra-specific competition pressure (Lewis et al. 2001, Oppel et al. 2015, Wakefield et al. 2017). To accurately predict murrelet at-sea distributions to unsampled colonies it is essential that: a) population estimates are obtained for all known Japanese Murrelet colonies (Table $\mathrm{S}_{2}$ ); and b) at-sea surveys are undertaken at colonies in different oceanographic regimes.

\section{Potential at-sea threats identified by model predictions}

Our results indicate that murrelets breeding on neritic colonies do not range far, and that murrelets from offshore islands commute to the mainland shelf to forage. This neritic distribution puts murrelets at greater threat from interaction with anthropogenic marine activities. Murrelets are 
sensitive to marine pollution and have been killed in oil spills, alongside large numbers of other alcids (Sato 1999). In addition to occasional large oil spills, the effects of numerous chronic oil spills from shipping poses a significant threat to seabird population stability (Camphuysen and Heubeck 2001, Wiese and Robertson 2004). The proximity of murrelet colonies to major ports and shipping lanes (e.g. Northern Izu colonies to Tokyo Bay), likely exposes breeding murrelets to the persistent threat of oiling while foraging (Carter et al. 2002). A neritic distribution also exposes breeding murrelets to a higher risk of disturbance and displacement impacts from offshore wind farms (Busch et al. 2013, Furness et al. 2013), pertinent in Japan given their expansion is promoted in the wake of the 2011 Fukushima nuclear disaster (Busch et al. 2013). Finally, a neritic distribution also exposes breeding murrelets to higher gillnet bycatch as most nets are set within 20 nautical miles of the coast (Waugh et al. 2011). As murrelets forage throughout the water column (Moyer 1957, Piatt and Gould 1994) they potentially interact with both coastal driftnets (targeting tuna and salmon), and bottom-anchored gillnets (targeting flatfish and greenling) in Japanese coastal waters (Ogi and Shiomi 1991). Given that Japan reports one of highest annual gillnet catches (Waugh et al. 2011), we reiterate here the need for monitoring of seabird bycatch in small-scale gillnet fisheries within the Japanese EEZ (Piatt and Gould 1994, Carter et al. 2002, Ogi 2008, Žydelis et al. 2013).

\section{Supplementary Material}

To view supplementary material for this article, please visit https://oi.org/10.1017/ So95927091800028X

\section{Acknowledgements}

We thank The Tiffany \& Co. Foundation, whose support was made possible through a grant to American Friends of BirdLife International, The Keidanren Nature Conservation Fund, The Nippon Foundation and Kaburagi Kikin for partial financial support for the project. We thank T. Yamamoto, S. Oppel, F. Daunt, M. Derhe and two anonymous referees who provided valuable comments that improved the manuscript.

\section{References}

Ashmole, N. P. (1963) The regulation of numbers of tropical oceanic birds. Ibis 103: 458-473

Bates, D., Maechler, M., Bolker, B. and Walker, S. (2015) Fitting Linear MixedEffects Models Using lme4. J. Stat. Software 67: 1-48.

BEAM (2014) Basic ers and envisat (a) atsr and meris toolbox (beam). Geesthacht, Germany: Brockmann Consult GmbH.

BirdLife International (2010) Marine Important Bird Areas toolkit: standardized techniques for identifying priority sites for the conservation of seabirds at sea. Cambridge, UK: Birdlife International.

BirdLife International (2015) Species factsheet: Synthliboramphus wumizusume. http://www.birdlife.org/datazone/ speciesfactsheet.php?id=3314 (accessed Oct 2013).
BirdLife International Tokyo, Wild Bird Society of Japan (2017) Marine IBA Inventory Important Areas for Seabird and Marine Conservation in Japan. Tokyo, Japan: Birdlife International Tokyo.

Bjornstad, O.N. (2015) ncf: Spatial Nonparametric Covariance Functions. R package version I.1.

Bolker, B. M., Brooks, M. E., Clark, C. J., Geange, S. W., Poulsen, J. R., Stevens, M. H. H. and White, J. S. S. (2009) Generalized linear mixed models: a practical guide for ecology and evolution. Trends Ecol Evol. 24: 127-135.

Busch, M., Kannen, A., Garthe, S. and Jessopp, M. (2013) Consequences of a cumulative perspective on marine environmental impacts: Offshore wind farming and seabirds at north sea scale in context of the EU marine strategy framework directive. Ocean Coastal Manage. 71: 213-224. 
Camphuysen, C. and Heubeck, M. (2001) Marine oil pollution and beached bird surveys: The development of a sensitive monitoring instrument. Environ. Poll. 112: 443-461.

Carter, H. R., Ono, K., Fries, J. N., Hasegawa, H., Ueta, M., Higuchi, H., Moyer, J. T., Ochikubo Chan, L. K., De Forest, L. N., Hasegawa, M. and Van Vliet, G. B. (2002) Status and conservation of the Japanese Murrelet Synthliboramphus wumizusume in the izu islands, japan. J. Yamashina Inst. Ornithol. 33: 61-87.

CBD (2010) Aichi biodiversity target 11 Technical Rationale extended. https://www. cbd.int/sp/targets/rationale/target-II/ (accesssed o8 Feb 2015).

Croxall, J. P., Butchart, S. H. M., Lascelles, B., Stattersfield, A. J., Sullivan, B., Symes, A. and Taylor, P. (2012) Seabird conservation status, threats and priority actions: A global assessment. Bird Conserv. Internatn. 22: 1-34.

DeGange, A. R., Day, R. H., Takekawa, J. E. and Mendenhall, V. M. (1993) Losses of seabirds in gill nets in the north pacific. Pp. 204-211 in K. Vermeer, K.T. Briggs, K. H. Morgan and D. Siegel-Causey, eds. The status, ecology and conservation of marine birds of the north pacific. Ottawa, Canada: Canadian Wildlife Service.

Dormann, C. F., McPherson, J. M., Araújo, M. B., Bivand, R., Bolliger, J., Carl, G., Davies, R. G., Hirzel, A., Jetz, W., Daniel Kissling, W., Kühn, I., Ohlemüller, R., Peres-Neto, P. R., Reineking, B., Schröder, B., Schurr, F. M. and Wilson, R. (2007) Methods to account for spatial autocorrelation in the analysis of species distributional data: A review. Ecography 30: 609-628.

Furness, R. W., Wade, H. M. and Masden, E. A. (2013) Assessing vulnerability of marine bird populations to offshore wind farms. J. Environ. Manage. 119: 56-66.

GEBCO (2014) The gebco 2014 grid, version 20100927. http://www.gebco.net (accessed Jan 2013).

Grecian, W. J.,Witt, M.J.,Attrill, M. J., Bearhop, S. Godley, B. J., Grémillet, D., Hamer, K. C. and Votier, S. C. (2012) A novel projection technique to identify important at-sea areas for seabird conservation: An example using Northern gannets breeding in the North East Atlantic. Biol. Conserv. 156: 43-52.
Hasegawa, H. (1984) Status and conservation of seabirds in japan, with special attention to the short-tailed albatross. Pp. 487-500 in J. P. Croxall, P. G. H. Evans and R. W. Schreiber, eds. Status and conservation of the world's seabirds. Cambridge, UK: International Council for Bird Preservation.

Hijmans, R. J. (2014) raster: Geographic Data Analysis and Modeling. $\mathrm{R}$ package version 2.2-5. http://CRAN.R-project.org/ package $=$ raster.

Iida, T. (2008) The first confirmation of the non-breeding habitat of Japanese Murrelets Synthliboramphus wumizusume. Ornithol. Sci. 7: 163-165.

Kantei (2007) Basic Act on Ocean Policy (Act No. 33 of April 27, 2007). https://www. kantei.go.jp/jp/singi/kaiyou/konkyo5.pdf (accessed May 2014).

Kissling, M. L., Gende, S. M., Lewis, S. B. and Lukacs, P. M. (2015) Reproductive performance of Kittlitz's Murrelet in a glaciated landscape, icy bay, Alaska, USA. Condor 117: 237-248.

Lascelles, B., Notarbartolo Di Sciara, G., Agardy, T., Cuttelod, A., Eckert, S., Glowka, L., Hoyt, E., Llewellyn, F., Louzao, M., Ridoux, V. and Tetley, M. J. (2014) Migratory marine species: Their status, threats and conservation management needs. Aquat. Conserv.: Mar. Freshw. Ecosyst. 24: 111-127.

Lavers, J. L., Miller, M. G., Carter, M. J., Swann, G. and Clarke, R. H. (2014) Predicting the spatial distribution of a seabird community to identify priority conservation areas in the Timor Sea. Conserv. Biol. 28: 1699-1709.

Lefcheck, J. S. (2016) piecewiseSEM: Piecewise structural equation modeling in $\mathrm{R}$ for ecology, evolution, and systematics. Meth. Ecol. Evol. 7: 573-579.

Lewis, S., Sherratt, T. N., Hamer, K. C. and Wanless, S. (2001) Evidence of intra-specific competition for food in a pelagic seabird. Nature 412: 816-819.

Louzao, M., Bécares, J., Rodríguez, B., Hyrenbach, K. D., Ruiz, A. and Arcos, J. M. (2009) Combining vessel-based surveys and tracking data to identify key marine areas for seabirds. Mar. Ecol. Progr. Ser. 391: 183-197. 
Ministry of Environment Japan (2011) Marine Biodiversity Conservation Strategy. http:// www.env.go.jp/nature/biodic/kaiyo-hozen/ pdf/pdf_pf_eng_all.pdf (accessed Jun 2014).

Mizutani, Y., Tomita, N., Niizuma, Y. and Yoda, K. (2013) Environmental perturbations influence telomere dynamics in longlived birds in their natural habitat. Biol. Lett. 9: 20130511.

Moyer, J. T. (1957) Birds of Miyake Jima, Japan. The Auk 74: 215-228.

NACS-J (2012) The way how Marine Protected Areas in Japan should be: to promote biodiversity conservation. www.nacsj.or.jp/ diary2/images/pdf/mpa_nacsj.pdf (accessed Jun 2014).

Nakagawa, S. and Schielzeth, H. (2013) A general and simple method for obtaining $\mathrm{r}^{2}$ from generalized linear mixed-effects models. Meth. Ecol. Evol. 4: 133-142.

Nielsen, S. E., Johnson, C. J., Heard, D. C. and Boyce, M. S. (2005) Can models of presenceabsence be used to scale abundance? Two case studies considering extremes in life history. Ecography 28: 197-208.

Oceancolor (2015) Ocean color level-2 data products. http://oceancolor.gsfc.nasa.gov/ DOCS/Ocean_Color_Level-2_Data_ Products.pdf (accessed Mar 2013).

Ogi, H. (2008) International and national problems in fisheries seabird by-catch. J. Disaster Res. 3: 187-195.

Ogi, H. and Shiomi, K. (1991) Diet of murres caught incidentally during winter in Northern Japan. The Auk 108: 184-185.

Ogi, H., Yatsu, A., Hatanaka, H. and Nitta, A. (1993) The mortality of seabirds by driftnet fisheries in the North Pacific. Internatn. North Pacific Fisheries Commission Bull. 53: 499-518.

Ono, K. (1996) Basic data about the rare wild aquatic organisms in japan. Japan Fisheries Resource Conserv. Assoc. 7: 514-519.

Oppel, S., Meirinho, A., Ramírez, I., Gardner, B., O'Connell, A. F., Miller, P. I., Louzao, M. (2012) Comparison of five modelling techniques to predict the spatial distribution and abundance of seabirds. Biol. Conserv. 156: 94-104.

Oppel, S., Beard, A., Fox, D., Mackley, E., Leat, E., Henry, L., Clingham, E., Fowler, N., Sim, J., Sommerfeld, J., Weber, N., Weber, S. and
Bolton, M. (2015) Foraging distribution of a tropical seabird supports Ashmoles hypothesis of population regulation. Behav. Ecol. Sociobiol. 69: 915-926.

Oppel, S., Weber, S., Weber, N., Fox, D., Leat, E., Sim, J., Sommerfeld, J., Bolton, M., Broderick, A. C. and Godley, B. J. (2017) Seasonal shifts in foraging distribution due to individual flexibility in a tropical pelagic forager, the Ascension frigatebird. Mar. Ecol. Progr. Ser. 585: 199-212.

Paiva, V.H., Geraldes, P., Ramírez, I., Meirinho, A., Garthe, S. and Ramos, J. A. (2010a) Foraging plasticity in a pelagic seabird species along a marine productivity gradient. Mar. Ecol. Progr. Ser. 398: 259-274.

Paiva, V. H., Geraldes, P., Ramírez, I., Meirinho, A., Garthe, S. and Ramos, J. A. (2010b) Oceanographic characteristics of areas used by Cory's shearwaters during short and long foraging trips in the North Atlantic. Mar. Biol. 157: 1385-1399.

Piatt, J. F. and Gould, P. J. (1994) Postbreeding dispersal and drift-net mortality of endangered Japanese Murrelets. The Auk I11: 953-961.

Potts, J. and Elith, J. (2006) Comparing species abundance models. Ecol. Modell. 199: 153-163.

QGIS Development Team (2013) QGIS Geographic Information System. Open Source Geospatial Foundation Project. http://qgis.osgeo.org.

R Development Core Team (2014) R: A language and Environment for Statistical Computing. Vienna, Austria: R Foundation for Statistical Computing. https://www.rproject.org .

Sato, H. (1999) Oil pollution damage of seabirds in the Sea of Japan that occurred in January 1986. J. Yamashina Inst. Ornithol. 31: 134-141.

Sealy, S. G., Pyle, P. and Carter, H. R. (2015). Ancient Murrelets molt flight feathers after the precocial young become independent. Northwestern Naturalist 96: 212-221.

Shoji, A., Yoneda, M. and Gaston, A. J. (2012) Ocean climate variability links incubation behaviour and fitness in Ancient Murrelets Synthliboramphus antiquus. Can. J. Zool. 90: 361-367.

Soanes, L. M., Bright, J. A., Angel, L. P., Arnould, J. P. Y., Bolton, M., Berlincourt, M., 
Lascelles, B., Owen, E., Simon-Bouhet, B. and Green, J. A. (2016) Defining marine important bird areas: Testing the foraging radius approach. Biol. Conserv. 196: 69-79.

Thaxter, C. B., Lascelles, B., Sugar, K., Cook, A. S., Roos, S., Bolton, M., Langston, R. H. and Burton, N. H. (2012) Seabird foraging ranges as a preliminary tool for identifying candidate marine protected areas. Biol. Conserv. 156: 53-61.

Wakefield, E. D., Phillips, R. A. and Matthiopoulos, J. (2009) Quantifying habitat use and preferences of pelagic seabirds using individual movement data: A review. Mar. Ecol. Progr. Ser. 391: 165-182.

Wakefield, E. D., Owen, E., Baer, J., Carroll, M. J., Daunt, F., Dodd, S. G., Green, J. A., Guilford, T., Mavor, R. A., Miller, P. I., Newell, M. A., Newton, S. F., Robertson, G. S., Shoji, A., Soanes, L. M., Votier, S. C., Wanless, S. and Bolton, M. (2017) Breeding density, fine scale tracking and large scale modeling reveal the regional distribution of four seabird species. Ecol. Applic. 27: 2074-2091.

Waugh, S., Filippi, D., Blyth, R. and Filippi, P. (2011) Report to the convention on migratory species assessment of bycatch in gill net fisheries zo September 2011. Wellington, New Zealand: Sextant Technology.

Wiese, F. K. and Robertson, G. J. (2004) Assessing seabird mortality from chronic oil discharges at sea. J. Wildl. Manage. 68: 627-638.

Wilson, L. J., McSorley, C. A., Gray, C. M., Dean, B. J., Dunn, T. E., Webb, A. and Reid, J. B. (2009) Radio-telemetry as a tool to define protected areas for seabirds in the marine environment. Biol. Conserv. 8: 1808-1817.

Zuur, A., Ieno, E., Walker, N., Saveliev, A. and Smith, G. (2009) Mixed effects models and extensions in ecology with R. New York, USA: Springer Science and Business Media.

Žydelis, R., Small, C. and French, G. (2013) The incidental catch of seabirds in gillnet fisheries: A global review. Biol. Conserv. 162: 76-88.

\title{
MARK G. R. MILLER ${ }^{* 1}$, MAYUMI SATO, BEN LASCELLES, PHIL TAYLOR
}

BirdLife International, Wellbrook Court, Girton Road, Cambridge, CB3 oNA, UK. ${ }^{1}$ and College of Science and Engineering and Centre for Tropical Environmental and Sustainability Science, James Cook University, Cairns, Queensland 4870, Australia.

\author{
YUTAKA YAMAMOTO, HITOSHI SATO, YASUHIRO ANDO, ITSURO EZAKI, SEIJI \\ HAYAMA, YUTAKA KOBAYASHI \\ Wild Bird Society of Japan, Maruwa Bldg, 3-9-23 Nishi-gotanda, Shinagawa-ku, \\ Tokyo 141-0031, Japan.
}

\section{YUTAKA NAKAMURA}

Miyazaki University, 1-1, Gakuen Kibanadai-nishi, Miyazaki-shi, Miyazaki 889-2192, Japan.

\section{SHIGEAKI MORI}

Hoshizaki Green Foundation, 1659-5, sono-cho, Izumo-shi, Shimane 691-oo76, Japan.

*Author for correspondence; e-mail:mark.gr.miller@gmail.com

Received 27 August 2017; revision accepted 19 August 2018;

Published online 29 November 2018 